\title{
EFISIENSI PEMBELAJARAN PAI MELALUI KEGIATAN PERBAIKAN KINERJA BERKELANJUTAN PADA KELOMPOK KEGIATAN GURU PAI KECAMATAN RAPPOCINI KOTA MAKASSAR
}

\section{ISLAMIC OF EDUCATION SUBJECT LEARNING THROUGH EFFICIENCY IMPROVEMENT ACTIVITIES ON SUSTAINABLE PERFORMANCE GROUP ACTIVITIES TEACHERS OF ISLAMIC RELIGIOUS SUBJECT IN MAKASSAR CITY}

\author{
M. YusufT. \\ Universitas Islam Negeri Alauddin Makassar \\ Jl. HM.Yasin Limpo No.36 Romangpolong-Kabupaten Gowa \\ Email: yusta72@gmail.com \\ Muhammad Rusydi Rasyid \\ Universitas Islam Negeri Alauddin Makassar \\ Jl. HM.Yasin Limpo No.36 Romangpolong-Kabupaten Gowa \\ Email: mrusydi1972@gmail.com \\ Muhammad Rapi \\ Universitas Islam Negeri Alauddin Makassar \\ Jl. HM.Yasin Limpo No.36 Romangpolong-Kabupaten Gowa \\ Email: mrapi@uin-alauddin.ac.id
}

Naskah diterima tanggal 15 September 2016. Naskah direvisi tanggal 3 Oktober 2016. Naskah disetujui tanggal 9 November 2016.

\begin{abstract}
Abstrak
Penelitian ini bertujuan meningkatkan kinerja pembelajaran guru melalui program Perbaikan Kinerja Berkelanjutan (PKB) pada Kelompok Kegiatan Guru (KKG) Pendidikan Agama Islam (PAI) Kecamatan Rappocini Kota Makassar. Masalah penelitian yang diajukan terkait dengan bagaimana meningkatkan kinerja pembelajaran guru pada kelompok guru sasaran melalui pendampingan PKB. Penelitian dilakukan dengan menerapkan metode action research yang didesain mengikuti siklus plan (merencanakan), do (melakukan) dan see (mengamati) yang secara operasional diimplemenasi secara bergilir pada 3 (tiga) sekolah berbeda: SDN Kompleks Pemda Makassar, SDN Kompleks IKIP 1 Makassar dan SDN Inpres Aroeppala Makassar. Hasil penelitian menunjukkan: (1) pengorganisasian PKB pada KKG PAI efektif mendorong motivasi guru untuk merubah cara pandangnya terhadap pembelajaran; (2) pengorganisasian PKB pada KKG PAI efektif mendorong perbaikan kinerja pengelolaan kelas; (3) pengorganisasian PKB pada KKG PAI efektif mendorong perbaikan kinerja pengelolaan bahan pembelajaran, dan (4) pengorganisasian PKB pada KKG PAI efektif mendorong kinerja evaluasi pembelajaran. Penelitian ini berimplikasi pada peningkatan motivasi, komitmen professional dan kinerja pembelajaran guru di dalam kelas.
\end{abstract}

Kata Kunci: guru, kinerja guru, kinerja berkelanjutan, pendidikan Islam.

\begin{abstract}
This study aims to improve the learning performance of teachers through Sustainable Performance Improvement Program (PKB) on Teacher Activity Group (KKG) on Islamic Religious Education subject (PAI) Rappocini District of Makassar. The research problem was composed related to the question, how to increased teacher's learning performance trough sustainable anggegment. The study was conducted by the method of action research which are designed to follow the cycle of plan, do, and see which operations are conducted in rotation on three (3) different schools: SDN Kompleks Pemda Makassar, SDN Kompleks IKIP 1 Makassar dan SDN Inpres Aroeppala Makassar. The results shown: (1) organizing PKB at KKG PAI
\end{abstract}


effectively motivate teachers to change the outlook on learning; (2) organizing PKB on KKG PAI effectively in encouraging improved teacher's performance in classroom management; (3) organizing PKB on KKG PAI effectively encouraging improved teacher's performance in management of learning materials, and (4) organizing PKB on KKG PAI effectively drive teacher's performance evaluation. It implicated to increasing teacher's motivation, professional commitment and their classes learning performance.

Keywords: teacher, teacher's performance, sustainable performance, Islamic education.

\section{PENDAHULUAN}

Peningkatan mutu pembelajaran, sebagai bagian integral dari reformasi pendidikan nasional, saat ini seharusnya telah memasuki fase transformasi yang ditandai dengan perbaikan menyeluruh pada keseluruhan komponen dan aspek pendukungnya sehingga efektif mendukung pencapaian pendidikan nasional. Melalui UU. No. 20 Tahun 2003 tentang Sistem Pendidikan Nasional, pundamental pendidikan yang etatis telah beralih ke pemberdayaan dimana unit terkecil pembelajaran yaitu kelas berkekuatan untuk mengembangkan metode, strategi maupun taktik untuk mencapai tujuan pembelajaran yang sesuai dan dibutuhkan. Secara nasional, perubahan tersebut telah direspon dengan perubahan-perubahan hingga ke lingkup mikro pendidikan seperti kurikulum (Miarso, 2009: 283).

Kurikulum 2013 yang dicanangkan sejak tahun 2012 adalah salah satu komponen penting transformasi tersebut. Kurikulum 2013 pada hakekatnya adalah upaya terpadu untuk merekonstruksi kompetensi lulusan dengan materi atau bahan; dengan proses pembelajaran; dan dengan evaluasi pembelajaran. Setelah mengalami uji coba dan implementasi pada sekolah di wilayah terbatas, kurikulum 2013 ternyata dipandang belum siap sehingga memaksa pemerintah untuk menunda implementasinya sampai dipandang cukup untuk didifusikan ke setiap sekolah dalam skala nasional.

Upaya difusi dalam skala nasional bukanlah perkara mudah untuk dilakukan. Faktor-faktor adopsi terhadap diferensiasi baik geografis maupun demografis adalah faktor-faktor klasik yang penting diperhatikan selain faktor-faktor yang secara global mempengaruhi politik pendidikan secara global sehingga suatu perubahan dapat diimplementasi secara paripurna (Cummings, 2010: 19-20). Secara teori, karakterisasi persepsi adopter terhadap suatu inovasi adalah kunci penting suatu perubahan dapat didifusikan.Artinya, pendidikan dan pelatihan yang tidak disertai dengan pendampingan berkelanjutan sulit diharapkan dapat mengoptimalkan peranan guru dalam mencapai tujuan kurikulum. Pembinaan atau pemdampingan guru acapkali dimaknai sebagai serangkaian usaha bantuan kepada guru (Uno, 2012: 169)

Secara sederhana, pendampingan berkelanjutan guru dimaksudkan sebagai upaya sekelompok profesional pembelajaran untuk memfasilitasi guru agardapat menguasai kompetensi profesionalnya dalam suatu paket pendampingan pembelajaran yang disusun secara terpadu (Fullan, 2007: 102). Terpadu (holism) adalah pendekatan yang menempatkan tigaaspek utama pembelajaran: teknis seperti metode pembelajaran, instrumental seperti perangkat pembelajaran, dan psikologis seperti kepercayaan diri guru sebagai suatu kesatuan utuh untuk mendukung pencapaian tujuan.

Aspek utama di atas seharusnya tampak dalam kinerja guru sehingga mereka mampu mengampuh pembelajaran secara efektif. Efektifasi pengampuhan itu menjadi ciri dasar guru profesional yang oleh Fullan (Hawley, 2007: 8-9) disebut sebagai perkembangan profesional yang substantif menopang perkembangan karir guru, mengorganisasi sekolah sebagai pendukung komunitas belajar dan upaya mereformasi lembaga pendidikan dan keguruan.

Faktanya, pola pelatihan guru belum tampak cukup memberi dampak menyeluruhbagi perbaikan mutu pembelajaran. Salah satu faktornyaadalahdiskrepansi yang cukup lebar antara pengalaman individual guru dengan yang apa semestinya dia capai dalam pembelajaran (Clayden, et all., 2003: 103-104). Beberapa guru dalam kelompok mata pelajaran telah mengalami perubahan namun masih sulit untuk mengendalikan kelas agar benar-benar mencapai tujuan dengan baik. Ditengarai permasalahan implementasi terletak pada intensitas pelatihan yang tidak disertai dengan monitoring yang efektif karena keterbatasan personil pelatih dan atau pengawas (Kirby, 2004: 6).

Akan halnya KKG PAI sebagai wadah pengembangan guru tingkat dasar (Jejen Musfah, 2015: 256) yang menjadi sasaran penelitian ini yang dipilih dari guru-guru PAI Sekolah Dasar yang tergabung pada dua kelompok yang dibagi berdasarkan kedekatan wilayah sekolah.Masingmasing KKG PAI beranggotakan guru-guru PAI 
yang berasal dari madrasah dan sekolah umum yang ada dalam wilayahnya baik negeri maupun swasta.Program kegiatan KKG ini dikoordinasi oleh Kepala Seksi PAI di Kantorpada Kementerian Agama Kota Makassar yang secara berkala menjadwalkan pertemuan anggota yang pada umumnya membicarakan persoalan pembelajaran. Dalam pertemuan itu biasanya dihadiri oleh seorang pengawas dan tamu ahli dari perguruan tinggi atau instansi lain yang kompeten. Pola pelatihan ini oleh pengawas dianggap belum memadai sehingga membutuhkan pola lain yang lebih intensif.

Ajuan program ini diformulasi dalam tema Pendampingan Berkelanjutan. Ide pokok dari terminologi ini adalah, guru yang tergabung dalam KKG PAI akan didampingi dengan cara difasilitasi oleh seorang atau beberapa orang pendamping untuk mengeksplorasi pemahaman awalnya tentang pembelajaran. Fasilitasi tersebut akan dilanjutkan dalam proses pengembangan pembelajaran oleh guru termasuk mendampingi mereka dalam mensimulasi hasilnya dalam lingkup terbatas. Pendampingan tersebut masih berlanjut hingga implementasinya di dalam kelas hingga selesai melakukan pembelajaran. Pasca pembelajaran, guru difasilitasi untuk melakukan refleksi atas pengalaman pembelajarannya termasuk melakukan evaluasi atas aktifitas itu. Kesimpulannya, aktifitas pendampingan akan dilakukan dengan model in-out-in, yaitu suatu pola pendampingan yang memadukan antara pendampingan in-class dan outclass. In-class adalah ruang yang digunakan bersama oleh pendamping dan guru KKG untuk berbagi pengalaman (shared experience) baik teori maupun menunjukkan best practices pembelajaran. Out-class adalah ruang yang digunakan oleh guru KKG PAI untuk mengimplementasi rancangannya pada fase in-class.

Tujuan utama penelitian ini adalah meningkatkan kinerja guru di dalam pembelajaran melalui kegiatan pendampingan berkelanjutan. Turunan dari tujuan ini meliputi: (1) mengidentifikasi permasalahan pembelajaran guru dalam mata pelajaran PAI pada KKG Rappocini; (2) mengenalkan teknologi pembelajaran sederhana kepada guru PAI pada KKG Rappocini untuk digunakan dalam menyelesaikan permasalahan kelasnya; (3) mengoptimalkan penggunaan teknologi pembelajaran sederhana kepada guru PAI pada KKG Rappocini dalam rangka meningkatkan kinerja pembelajaran.

\section{Tinjauan Pustaka}

Kinerja pembelajaran adalah salah satu peran selain kompetensi pengajaran yang harus dikuasai oleh guru. Mitrani (1995: 131) mendefinisikan kinerja descriptor untuk menjelaskan kemampuan seseorang untuk memainkan perannya dalam penyelenggaraan strategi organisasi, baik dalam mencapai sasaransasaran khusus yang berhubungan dengan peranan perseorangan, dan atau dengan memperlihatkan kompetensi-kompetensi yang dinyatakan relevan bagi organisasi, apakah dalam suatu peranan tertentu, atau secara lebih umum.

McClelland (1972: 46) mendefinisikan kinerja sebagai cerminan dari keseluruhan cara seseorang dalam menetapkan tujuan prestasinya. Seorang guru yang baik bekerja dengan perencanaan-perencanaan yang matang sehingga tujuan yang direncanakan dapat tercapai. Perbedaan kinerja antara seseorang dengan yang lain dalam suatu situasi kerja adalah karena perbedaan karakteristik dari individu.

\section{METODE PENELITIAN}

Penelitian ini menggunakan metode kualitatif yang lebih mengutamakan latar yang alamiah (Alwasliyah, 2011: 25), dan penelitian ini dirancang dengan mengikuti pola penelitian tindakan atau action research (AR) yang segaris dengan teknik partisipatori action reseacrch yang terbukti telah banyak digunakan dalam mendiagnosis problem yang spesifik dan termasuk solusinya (Mikkelsen, 2011:70). Penelitian berakar dariteologi pembebasan dan pengembangan masyarakat (Denzin, et.all, 2009: 438) Seperti lazimnya AR, penelitian ini dilakukan dengan mengikuti siklus pencapaian tujuan penelitian yang pada umumnya melalui proses reflecting dan action.Secara operasional, kedua prosedur tersebut diimplemetasi dalam lima tahapan: need assessment, enhancing performance, plan, do dan see.

Dua tahap pertama merupakan persiapan untuk melakukan action yang berarti plan, do dansee merupakan inti tindakan penelitian. Need assessment adalah tahap mengenal permasalahan subjek terkait kinerja yang wajib diampuhnya. Enhancing performance adalah tahap membekali subjek berbagai keterampilan pembelajaran untuk dia gunakan dalam merancang pembelajaran.

Plan adalah tahap merancang kegiatan pembelajaran berdasar temuan permasalahan pada tahap sebelumnya.Kegiatan ini meliputi 3 (tiga) 
kegiatan mendasar: analisis instruksional; desain instruksional; dan, mengembangkan hasilnya ke dalam rancangan pembelajaran. Hasil rencana itu kemudian dilanjuti dengan rancangan kegiatan tahapan selanjutnya, do.

Do adalah kegiatan dimana subjek dan peneliti berkolaborasi dalam mengaktualisasi rancangan melalui simulasi pembelajaran di dalam kelas. Kegiatannya meliputi: melaksanakan pembelajaran sesuai desain yang direncanakan sebelumnya; dan, merefleksikan pengalaman pembelajaran. Dua kegiatan inti ini dalam rancangan penelitian ini dikategorikan sebagai kegiatan out class.

Setelah kegiatan $d o$, peneliti dan subjek kembali ke dalam kelas (in class) untuk melihat (see) hasil simulasi nyata di dalam ruang kelas sekolah yang dipilih. Kegiatan ini secara umum melakukan: penilaian kinerja pembelajaran; menemukan praktek terbaik (best practices) pembelajaran; dan, mengevaluasi pencapaian tujuan pembelajaran.

\section{PEMBAHASAN}

Dalam kegiataan need assessment diperoleh fakta: (1) Guru SD PAI dalam KKG PAI Rappocini tidak memperoleh kesempatan yang sama dengan KKG guru mata pelajaran lain terutama mata pelajaran umum untuk mengikuti pelatihan peningkatan kompetensi dan kinerja pembelajaran; (2) Guru SD PAI dalam KKG PAI Rappocini telah memiliki struktur organisasi dan rencana kerjanamun kesulitan mengimplementasinya secara efektif karena kurangnya tenaga pelatih atau pendamping ahli dalam bidang PAI; (3) Guru SD PAI dalam KKG PAI Rappocinimembutuhkan pendamping atau pelatih ahli dalam pelatihan peningkatan keahlian professional guru; (4) Konten pelatihan peningkatan keahlian profesional dalam KKG PAI dirasakan belum cukup untuk meningkatkan keterampilan pengelolaan pembelajaran yang mendukung peningkatan kinerja mereka di dalam kelas.

Proses mengungkap permasalahan dilakukan dengan mengelompokkan guru dalam kelompok terbatas dimana berkesempatan untuk membagi pengalamannya dengan guru lain dari sekolah berbeda. Pengalaman berbagi ditemukan bukan hal mudah bagi guru. Dalam KKG umumnya guru berbagi keluh dan kesah. Dalam proses ini mereka berbagi pengalaman mengunjuk kinerja. Beberapa guru tampak tidak terbuka dan cenderung menyembunyikan pengalaman sebenarnya sehingga makin menantang untuk mendalaminya.
Mensiasati itu, dilakukan regrouping dimana guru dikelompokkan kembali berdasarkan asal sekolahnya.

Tampak kelompok baru ini lebih terbuka. Antara satu guru dengan guru lainnya terlihat lebih nyaman menyampaikan pengalamannya. Jika diidentifikasi, permasalahan guru menjurus pada arah yang sama: (1) relatif sulit mengembangkan indikator kompetensi pembelajaran; (2) relatif sulit menngembangkan strategi pembelajaran (metode, media dan penggunaan waktu) secara tepat sehingga relatif dominan menggunakan strategi konvensional dalam pembelajaran; (3) relatif sulit mensinkronkan antara kompentensi yang akan dicapai dengan bahan dan sumber pembelajaran yang sesuai; (4) relatif sulit mengembangkan sistem evaluasi otentik di dalam pembelajaran; (5) relatif sulit mensinkronkan kegiatan kelas dengan penguatan budaya literasi di sekolah.

Terhadap permasalahan-permasalahan di atas, dirancang kegiatan lanjutan berupa pelatihan untuk mendorong peningkatan kinerja pembelajaran (enhancing performance). Kegiatan ini hakikatnya adalah abstraksi dari penilaian kebutuhanyang dilakukan pada siklus sebelumnya yang tujuan utamanya adalah mendorong kinerja guru melalui aktifitas KKG PAI.Strategi ini ditempuh dengan harapan peserta pelatihan memiliki komitmen dan kepercayaan diri untuk menyelenggarakan kegiatan lanjutan dalam KKG pasca pelatihan.

Merujuk kepada Anderson (1984: 598) faktor individu dan faktor situasi dipertmbangkan untuk mengoptimalkan kinerja dimaksud. Faktanya, jika seseorang melihat kinerja tinggi merupakan jalur untuk memenuhi kebutuhannya, maka ia akan mengikuti jalur tersebut. Sedang faktor situasi merupakan hasil interaksi antara motivasi dengan kemampuan dasar. Artinya, jika individu memiliki motivasi tinggi namun kemampuan dasarnya rendah, maka dia akan menunjukkan kinerja rendah. Demikian pula, jika kemampuan tinggi dan motivasi yang dimiliki rendah maka kinerja akan rendah, atau sebaliknya.

Dalam hubungannya dengan guru, kinerja dapat didefinisikan sebagai upaya guru untuk memaksimalkan perannya sesuai dengan kemampuan yang dimilikinya dalam upaya mencapai tujuan instruksional yang dapat diamati dalam pembelajaran.

Penghindaran atas lemahnya motivasi guru dalam mengunjuk kinerjanya disiasati dengan membuka ruang seluas-luasnya kepada guru agar 
dapat berkontribusi secara maksimal di dalam pelatihan (Weigel, et al dalam Khin dan Saleh, 2010: 17). Abai atas aspek partisipasi ini akan berakibat pada lemahnya kemampuan guru untuk mengabtraksi situasinya secara optimal yang berguna baginya mencapai tujuan-tujuan tertentu pasca pendampingan (McKenzie, 2005: 6).

Kegiatan yang dihadiri oleh Pengawas Guru SD Kecamatan Rappocini dan dibuka oleh Kepala Sekolah SDN Inpres Aroepala ini diikuti oleh 30 orang Guru PAI.Pelatihan meliputi materi pengelolaan pembelajaran efektif yang muatannya meliputi: (1) pengelolaan kelasyang efektif, (2) active learning, dan (3) keterampilan membaca bermakna.

Ketiga materi di atas dimaksudkan untuk memberi pengalaman kepada guru untuk menciptakan 4 (empat) pilar dasar penciptaan lingkungan belajar di sekolah: available (dapat disiapkan), accessible (dapat digapai), acceptable (dapat diterima), dan adaptable (dapat diadaptasi) (UNESCO, 2013: 7-8).

Pada materi pengelolaan kelas efektif tampak bahwa guru PAI terbiasa menyelenggarakan pembelajaran satu arah, yaitu guru menyampaikan materi dan siswa menerima.Dalam relasi itu, guru menjadi sumber utama baik dalam menentukan atau menginterpretasi isi bahan.Akibatnya, hasil yang dicapai tidak optimal mencapai tujuan pembelajaran.Selain itu, patronase yang diakibatkannya menjadikan siswa jadi penghapal bahan dan tidak jarang kehilangan atensi belajar.

Melalui materi ini, kepada guru dikenalkan teknik-teknik pembelajaran berbasis meaningfull ditambah teknik pengelolaan kelas yang relevan dengan pembelajaran berbasis kelas seperti halnya mata pelajaran PAI. Melalui materi ini, guru dapat mengidentifikasi perannya dan peran siswa secara proporsional dalam aktifitas pembelajaran (Yusuf, 2015: 251). Melalui materi ini, guru juga dilatih mengorganisasi kelompok belajar siswa yang sangat penting dalam menyelenggarakan pembejaran berbasis aktifitas (active learning).

Aktifitas membaca bermakna dilatihkan khusus agar guru mampu memiliki kemampuan memahamkan teks kepada peserta didik sekaligus mendukung program budaya baca di sekolah. Membaca bermakna terdiri dari

Kegiatan membaca pada hakikatnya adalah program yang dirancang agar peserta didik melakukan aktifitas membaca. Beberapa keterampilan dasar dalam aktifitas ini dilatihkan seperti keterampilan memprediksi teks, keterampilan pemahaman kalimat, keterampilan pemahaman kosa kata sulit (termasuk mengenal tanda baca dan intonasi), keterampilan merangkum dalam bentuk verbal dan tulisan.

Materi lain adalah membaca pemahaman. Kegiatan membaca pemahaman meliputi membaca bersama dan membaca terbimbing. Kegiatan ini bertujuan membekali guru keterampilan mengajar yang memfasilitasi siswa kemampuan analisis melalui bacaan seperti memahami inti bacaaan, menduga, memprediksi, mempertanyakan dan menyimpulkan isi materi bacaan.

Dalam kegiatan ini terungkap bahwa itemitem kritis yang penting diperbaiki dari kinerja pembelajaran guru adalah: pengelolaan siswa, strategi pembelajaran, bentuk tugas, jenis kegiatan penugasan (mandiri, kelompok, atau berpasangan). Selain itu, pengenalan karakteristik kelas sering diabaikan terutama dalammemvariasikan berbagai strategi pembelajaran seperti kapan sebaiknya melakukan ceramah, menyelenggarakan diskusi atau bekerja secara kolaboratif. Demikian pula aspek strategi pembelajaran lainnya seperti optimalisasi pembelajaran PAIKEM, pemecahan masalah, project based, menghasilkan produk, menemukan, dan seterusnya (Suprijono, 2013: 89).

Hasil pelatihan ini dijadikan referensi untuk menyusun perencanaan (plan) pembelajaran. Peserta didorong untuk menghasilkan suatu rancangan yang meliputi: pengelolaan pembelajaran efektif; penyelenggaraan pembelajaran aktif dan kreatif; penyelenggaraan pembelajaran dengan pendekatan saintifik; pengembangan pembelajaran project based dan inquiry based; pemilihan media pembelajaran yang sesuai; pengelolaan lembar kerja siswa untuk mencapai kompetensi pembelajaran; mengembangkan kepemimpinan dalam pembelajaran; persiapan praktik pembelajaran.

Efektivasi atas kinerja tersebut, guru dikelompokkan berdasarkan kelas dan unit tugas masing-masing. Terkait dengan persiapan praktik mengajar, kelompok dibagi dalam 10 rombel dan tiap kelas terdiri dari kelas 1, 2, 3 dan 4 masing-masing 2 rombel dengan mengacu pada gugus kelompok guru sehingga mudah dikoordinasi. Di dalam kelompok, guru berdiskusi dengan pasangannya, menyesuaikan berbagai komponen desain, menghubungkan dan memastikan relevansinya satu sama lain. Hasilnya kemudian dikembangkan menjadi Rencana Pelaksanaan Pembelajaran (RPP) yang siap digunakan dalam praktek mengajar sekanjutnya. 
Setelah tiba pada waktu yang disepakati, para guruberkumpul diSDNIKIP 1 Kecamatan Rappocini untuk memeriksa, mereviu dan menyempurnakan rancangan untuk selanjutnya dipraktikkan melalui kegiatan simulasi. Dalam penelitian ini, tahap ini disebut tahap do (melakukan) yang intinya untuk mengamati secara seksama aspek kesesuaian dan praktis perencanaan yang telah disusun sebelumnya secara berkelompok.

Prosesnya didahului memeriksa setiap komponen berdasarkan instrumen daftar periksa pengkajian perangkat pembelajaran yang disiapkan peneliti. Daftar periksa tersebut digunakan untuk menyisir komponennya satu persatu oleh guru di dalam kelompoknya. Instrumen ini juga digunakan oleh kelompok untuk menilai RPP dengan teknik karya kunjung, yaitu karya kelompok lain diperiksa dan dinilai oleh kelompok berbeda. Kelompok kemudian merevisi seperlunya dan hasilnya dipresentasikan dimana peserta lain diberi kesempatan menanggapinya. Kegiatan ini diakhiri dengan penguatan oleh pendamping.

Kegiatan selanjutnya adalah simulasi pembelajaran, peserta yang tidak sedang praktik berperan sebagai peserta belajar. Untuk membantu peserta dalam simulasi tersebut, disiapkan lembar amatan sehingga pengamatan lebih terarah. Pada kesempatan ini ada 2 orang guru melakukan simulasi dengan memilih big book sebagai media pembelajaran PAI.Big book adalah media yang umumnya digunakan dalam pembelajaran literasi namun dinilai juga relatif efektif digunakan dalam pembelajaran agama.

Guru pertama, mempraktekkan big book pada materi berwudhu. Guru tersebut memulai dengan meminta peserta memprediksi materi yang akan diajarkan. Guru bertanya kepada peserta sebagai bagian dari stimulasi perhatian peserta terhadap materi. Kemudian guru membaca materi dan meminta peserta untuk mengikutinya. Kegiatan itu berulang hingga detil cara berwudhu dapat dipahami. Kelebihan penggunaan media ini teramati bersumber dari teksnya yang singkat dan sederhana serta ilustrasi yang mengasosiasi kompetensi.

Setelah simulasi mengajar dilaksanakan, peserta diberi kesempatan menanggapi sekaligus memberi input dengan harapan rancangan yang telah dipraktekkan nantinya dapat digunakan secara maksimal pada tahap see. Beberapa catatan menunjukkan bahwa penggunaan kalimat sederhana lebih efektif menyampaikan kepada tujuan. Penyesuaian tata letak gambar serta komposisi warna dan kesesuaian dengan materi dapat menimbulkan ketertarikan yang tinggi. Catatan lain menunjukkan improvisasi berupa gerak perlu memperhatikan dimensinya agar siswa lebih mudah menangkap maksud dan tujuannya. Selain itu ternyata ajuan pertanyaan sederhana kepada siswa dibutuhkan untuk menambah konsentrasi dan fokus.

Tahap do ini diakhiri dengan meminta peserta atau subjek penelitian untuk menyiapkan perangkat-perangkat pembelajaran untuk dibawa ke fase berikutnya,see yaitu fase mengajar yang sesungguhnya, di dalam kelas dan dihadiri oleh siswa sesungguhnya.

Fase see dilaksanakan di SD Inpres BTN Pemda Kecamatan Rappocini, Makassar. Rancangan pembelajaran nyata (real teaching) ini mengadopsi teknik lesson learn. Guru yang adalah subjek penelitian dan terlatih pada siklus sebelumnya dikelompokkan dalam pasangan berdua.

Siklussee dimulaidenganmemberikesempatan kepada para guru untuk memperaktikkan hasil yang diperoleh pada siklus do sebelumnya. Peserta dibagi dalam beberapa kelompok mengajar, pada kelas I sampai dengan V. Sementara peserta yang menjadi pasangannya bertugas mengamati selama proses berlangsung (peer teaching).

Setelah proses praktik mengajar selesai para peserta dikumpulkan dalam ruangan untuk melakukan refleksi atas pengalaman pembelajaran dengan rancangan yang mereka sepakati. Secara umum mereviu bahwa strategi yang dirancang belum optimal dapat diaplikasi secara optimal dalam praktik dalam kelas. Catatan tersebut secara umum disebutkan muncul karena aspek-aspek psikologis, misalnya peserta belajar adalah siswa dari sekolah lain. Meski demikian, secara umum merasakan hasil pembelajaran yang lebih memuaskan.

\section{PENUTUP}

Hasil penelitian ini menyimpulkan pertama kelompok KKG PAI Kota Makassar jika didampingi secara berkelanjutan akan dapat compete dengan guru bidang studi lainnya. Kedua siklus plan, do dansee efektif digunakan dalam perbaikan kinerja pembelajaran guru berkelanjutan. Ketiga pengorganisasi pelatihan peningkatan kinerja pembelajaran guru PAI perlu diintensifkan sehingga mutu kualitas pembelajaran agama di sekolahsekolah umum dapat mencapai tujuan seperti yang diharapkan. 


\section{UCAPAN TERIMA KASIH}

Artikel yang ada di hadapan pembaca budiman, melibatkan kontribusi beberapa pihak, yang sejatinya patut mendapatkan apresiasi dari penulis berupa ucapan terima kasih, khususnya kepada para guru Pendidikan Agama Islam SD di Kecamatan Rappocini yang menjadi partisipan penelitian ini, dan juga terima kasih penulis haturkan kepada pengelola jurnal Al-Qalam yang telah memilih artikel ini menjadi bagian dari edisi ini.

\section{DAFTAR PUSTAKA}

Alwasliyah, A. Chaedar. 2011. Pokoknya Kualitatif. Jakarta: Pustaka Jaya.

Anderson, N. H. 1984. "Performance=Motivation and $\mathrm{x}$ Ability: An Integration Theoritial Analysis" dalam Journal of Personality and Social Psychology. 598604.

Clayden, et all. 2003. "Authentic Activity and Learning" dalam Anna Craft (ed), Primary Education: Assessing and Planning Learning. New York: Routledge.

Cummings, William K. 2000. "How Educational Form and Reform" dalam Joseph Zajda dan Macleans A. Geo-Jaja (eds), The Politics of Educational Reforms. New York: Springer.

Denzin, Norman, et.all. 2009. Handbook of Qualitatif Research. California: Sage Publication.

Fullan, Michael. 2007. The New Meaning of Educational Change. New York: Columbia University Press. 2007. "Educational Reform as Continous Improvement" dalam Hawley, Willis D. (ed). 2007. The Keys to Effective Schools: Educational Reform as Continous Improvement. London: Corwin Press.
Kirby, Sheila Nataraj; at all. 2004. Reforming Teacher Education. California: Rand Corporation.

McClelland, D. C. Winter. 1972. Motivation Economic Achievement. New York: The Free Press.

McKenzie, Walter. 2005. Multiple Intelligencies and Instructional Technology. Washington: International Society for Technology in Education.

Miarso, Yusuf Hadi. 2009. Menyemai Benih Teknologi Pendidikan. Jakarta: Prenada Media Grup.

Mikkelsen, Britha. 2011. Metode Penelitian Partisipatoris dan Upaya Pemberdayaan (Terj). Jakarta: Yayasan Obor.

Mitrani, et al. 1995. Manajemen Sumber Daya Manusia Berdasarkan Kompetensi. Jakarta: Pustaka Utama Graffiti.

Musfah, Jejen. 2015. Manajemen Pendidikan: Teori, Kebijakan dan Praktik. Jakarta: Prenadamedia.

Suprijono, Agus. 2013. Cooperative Laerning: Teori dan Aplikasi PAIKEM. Yogyakarta: Pustaka Pelajar.

UNESCO: Global Thematic Consultation on Education and the Post-2015 Development Framework. "Making Education for All a Reality". Beyong 2015 Position Paper. March 2013.

Uno, Hamzah B. 2012. Model Pembelajaran: Menciptakan Proses Belajar Mengajar yang Kreatif dan Efektif. Jakarta: PT Bumi Aksara.

Weigel, Margaret, et al. 2010. "New Digital Media and Their Potential Cognitive Impact on Youth Learning" dalam Myint Swe Khine dan Isa M. Saleh. New Science of Learning. New York: Springer.

YusufT., M. 2015. "Literasi Pengetahuan dan Implikasinya terhadap Keterampilan Menulis". Jurnal Lentera Pendidikan, Vol. 18 No. 2, 2015. 